\title{
UJI AKTIVITAS ANTIBAKTERI FRAKSI DAUN BIDURI (Calotropis gigantean L.) TERHADAP Staphylococcus aureus
}

\author{
Nurul Hidayah ${ }^{1}$, Choirul Huda ${ }^{1^{*}}$, Dara Pranidya Tilarso ${ }^{1}$ \\ ${ }^{1}$ Program Studi S1 Farmasi, STIKes Karya Putra Bangsa Tulungagung \\ email :Hudacoy85@gmail.com
}

\begin{abstract}
Staphylococcus aureus is a Gram-positive, clustered form. Staphylococcus aureus is a major cause of nosocomial infections, food poisoning, and toxic shock syndrome. Staphylococcus aureus infection cant occur when the immune system is weakened. Antibiotics are used as one of the ways to treat infection, but inappropriate use of antibiotics will cause resistance. Traditional medicine made from plant extract can be used as an alternative medicine to treat the infection. Traditional medicines derived from plants have far lower side effects than chemical drugs. One of the plants that can be used as medicinal ingredients is biduri plant (Calotropis gigantea L.). The purpose of this study was to determine the activity of Aquadestilata, ethyl acetate, and $n$-hexane fractions of biduri leaf extract as an antibacterial against Staphylococcus aureus bacteria. Calotropis gigantea leaves were extracted using maceration methods. Alcohol $70 \%$ was used as a solvent in the maceration procedure. Extract that we obtained, then undergone in fractionation procedure using Aquadestilata, ethyl acetate, and n-hexane as a solvent. The antibacterial activity of Calotropis gigantea leaves fraction was tested using the disc diffusion method with a series concentration of $10 \%, 20 \%$, and $30 \%$. One way ANOVA was used to statistically analyze the data obtained. In statistical analysis, we could found out whether the variation of the various concentration of Calotropis gigantea leaves fraction has any positive effect or not, against the growth of Staphylococcus aureus bacteria. The results of the research that has been done shown that Aquadestilata and ethyl acetate fraction have antibacterial activity. Aquadestilata fraction was the most active fraction that inhibits the activity of the bacteria Staphylococcus aureus. That was because it contains flavonoid compounds, tannins, and saponins. The optimum concentration of Calotropis gigantea leaves fractions to inhibits the growth of bacteria Staphylococcus aureus was $10 \%$, with an average inhibition zone was $6,33 \mathrm{~mm}$.
\end{abstract}

Keywords:antibacterial, Bithorn leaves, diffusion, fractionation, Staphylococcus aureus.

\begin{abstract}
ABSTRAK
Staphylococcus aureus adalah bakteri Gram positif yang berbentuk menggerombol. Bakteri Staphylococcus aureus merupakan penyebab utama infeksi nosokomial, keracunan makanan, dan sindrom syok toksik. Infeksi Staphylococcus aureus dapat terjadi ketika sistem imun melemah. Salah satu penanganan infeksi adalah menggunakan antibiotik, namun penggunaan antibiotik yang tidak tepat akan menimbulkan resistensi, sehingga terapi menggunakan obat tradisional menjadi pilihan alternatif. Obat tradisional yang berasal dari tanaman memiliki efek samping yang jauh lebih rendah tingkat bahayanya dibandingkan obat-obatan kimia. Salah satu tumbuhan yang dapat dimanfaatkan sebagai bahan obat adalah tanaman biduri (Calotropis gigantea L.). Tujuan penelitian ini adalah mengetahui aktivitas fraksi Aquadestilata, etil asetat dan $n$-heksan dari ekstrak daun biduri sebagai antibakteri terhadap bakteri Staphylococcus aureus. Daun biduri diekstraksi menggunakan metode maserasi dengan menggunakan pelarut alkohol $70 \%$ dan difraksinasi menggunakan pelarut Aquadestilata, etil asetat dan $n$-heksan. Uji aktivitas antibakteri fraksi daun biduri menggunakan metode difusi cakram dengan seri konsentrasi $10 \%$, 20\% dan 30\%. Analisis
\end{abstract}


statistik yang digunakan yaitu one way ANOVA yang bertujuan untuk mengetahui berpengaruh atautidaknya variasi konsentrasi fraksi daun biduri terhadap pertumbuhan bakteri Staphylococcus aureus. Hasil penelitian yang telah dilakukan menunjukkan bahwa fraksi Aquadestilata danetil asetat mempunyai aktivitas antibakteri. Fraksi Aquadestilata merupakan fraksi teraktif dalam menghambat aktivitas bakteri Staphylococcus aureus karena mengandung senyawa flavonoid, tanin dan saponin. Konsentrasi optimum fraksi daun biduri dalam menghambat pertumbuhan bakteri Staphylococcus aureus adalah $10 \%$ dengan rata-rata zona hambat sebesar 6,33 $\mathrm{mm}$.

Kata kunci:antibakteri, daun biduri, difusi, fraksinasi, Staphylococcus aureus.

\section{PENDAHULUAN}

Obat tradisional merupakan warisan budaya bangsa yang perlu dilestarikan dan juga dikembangkan guna untuk menunjang kesehatan.Tumbuhan obat merupakan keanekaragaman hayati yang dapat dibudidayakan. Sejak nenek moyang, tumbuhan sudah digunakan sebagai tanaman obat. Pengobatantradisional dipandang sebagai alternatif yang sangat terjangkau oleh masyarakat karena biayanya yang cukup murah(Dewantari, 2018). Salah satu tumbuhan yang dapat dimanfaatkan sebagai bahan obat adalah tanaman biduri (Calotropis gigantea L.) sebagai antibakteri Staphylococcus aureus.Pada hasil penelitian menyatakan manfaat dari tanaman biduri sebagai obat batuk, gatal-gatal, obat sakit gigi, obat sakit telinga, luka kesleo, dan juga diare (Nadziroh, 2014). Menurut Dewi et al. (2018), hasil skrining fitokimia ekstrak daun biduri mengandung senyawa metabolit sekunder yaitu, tanin, saponin, flavonoid, dan polifenol yang memiliki potensi sebagai antibakteri.

Metode yang digunakan untuk ekstraksi senyawa flavonoid, tanin, dan saponin pada daun biduri adalah metode maserasi. Metode maserasi digunakan karena lebih sederhana,relatif murah, menggunakan peralatan yang cukup sederhana, terjadi kontak langsung antara sampel dan pelarut cukup lama dan tidak merusak senyawa yang tidak tahan panas (Susanty dan Bachdim, 2016). Maserat yang dihasilkan dari ekstraksiselanjutnya dilakukan fraksinasi. Fraksinasi bertujuan untuk mendapatkan fraksi ekstrak yang lebih murni (Hasanah, 2019). Fraksi yang diperoleh kemudian dilakukan uji aktivitas antibakteri terhadap bakteri Staphylococcus aureus (Mutiasari, 2012).

Pengujian antibakteri pada penelitian ini dilakukan dengan menggunakan metode difusi cakram atau disk. Metode difusi cakram digunakan karena memiliki harga relatif murah, tidak memerlukan alat khusus dalam pengerjaannya, cepat dan mudah dilakukan (Katrin et al.,2014).

Berdasarkan latar belakang diatas, maka peneliti akan melakukan penelitian "Uji Aktivitas Antibakteri Fraksi Daun Biduri terhadapStaphylococcus aureus" untuk mengetahui aktivitas antibakteri dari fraksi daun biduri (Calotropis gigantea L.) terhadap pertumbuhan bakteri Staphylococcus aureusdengan metode difusi cakram yang menggunakan kontrol positif kloramfenikoldengan konsentrasi 10\%, 20\%, dan 30\%.

\section{BAHAN DAN METODE}

\section{BAHAN}

Sampel yang digunakan dalam penelitian ini adalah daun biduri yang didapat dari halaman Kampus STIKes Karya Putra Bangsa Tulungagung dan di Desa Gempolan, Kecamatan Pakel, Kabupaten Tulungagung. Bahan yang digunakan adalah Aquadestilata, etil asetat, $n$-heksan, etanol $70 \%$, media Nutrient Agar, media Nutrien broth, $\mathrm{NaCl}, \mathrm{HCl}$, magnesium, kloroform, $\mathrm{H}_{2} \mathrm{SO}_{4}$, asam asetat glasial, $\mathrm{Mg}$, danFeCl $\mathrm{F}_{3}$.

\section{METODE}

1. Pengambilan Sampel

Sampel yang digunakan dalam penelitian ini adalah daun biduri sebanyak $5 \mathrm{~kg}$ diperoleh di halaman Kampus STIKes Karya Putra Bangsa Tulungagung dan di Desa Gempolan, Kecamatan Pakel, Kabupaten Tulungagung. Diambil daun biduri yang masih segar. 
2. Pembuatan Simplisia

Daun biduri diambil pada bagian daun tua atau muda dengan cara dipetik, kemudian dilakukan sortasi basahuntuk menghilangkan bahan asing atau pengotor lainnya (Amelinda, 2018). Pencucian dilakukan dengan menggunakan air bersih yang mengalir untuk menghilangkan tanah dan pengotor lainnya yang melekat pada simplisia. Pencucian dilakukan sebanyak 3x agar simplisia benar-benar bersih. Pengeringan simplisia dilakukan dengan cara diangin-anginkan atau tidak terkena cahaya matahari secara langsung pada suhu kamar. Kemudian dilakukan sortasi kering untuk memisahkan simplisia dari kotoran atau bahan-bahan asing lainnya. Simplisia yang sudah kering kemudian dihaluskan dan diayak menggunakan ayakan no.mesh 80 sehingga dihasilkan serbuk daun biduri (Amelinda, 2018).

3. Ekstraksi

Serbuk simplisia daun biduri ditimbang sebanyak 500 gram. Proses selanjutnya yaitu memasukkan sembuk simplisia daun biduri dalam bejana maserasi, lalu ditambah dengan pelarut etanol $70 \%$ sebanyak 3.75 liter atau hingga terendam. Selanjutnya diaduk hingga homogen.Serbuk dalam bejana maserasi disimpan dalam ruangan yang terlindung dari sinar matahari secara langsung selama 5 hari.Selama perendaman setiap hari diaduk selama 15 menit. Setelah direndam selama 5 hari, disaring untuk mendapatkan maserat, maserat ditampung hasil ampas yang diperoleh dimaserasi lagi dengan jumlah penyari yang sama. Lalu filtrat hasil remaserasi dipekatkan dengan oven pada suhu $50^{\circ} \mathrm{C}$ hingga diperoleh ekstrak daun biduri.Menurut Kemit et al. (2015) semakin lama waktu maserasi maka kesempatan kontak antara bahan dan pelarut semakin besar sehingga hasilnya akan terus meningkat sampai pada titik jenuh dari pelarut tersebut.

4. Fraksinasi

Ditimbang sejumlah ekstrak 5 gram, dilarutkan menggunakan $75 \mathrm{ml}$ aquadestilata.Larutan sampel dimasukkan dalam corong pisah, ditambah dengan pelarut $n$-heksan $25 \mathrm{ml}$ di ulang sebanyak 3 kali sebagai pelarut non polar.Kemudian di aduk hingga tampak terjadi seperti pemisahan.Masing-masing ditampung di beaker glass.Fraksi air difraksinasi dengan etil asetat $25 \mathrm{ml}$ di ulang sebanyak 3 kali sebagai pelarut semi polar.Fraksi yang diperoleh dipekatkan sampai didapat fraksi yang kental (Hasanah, 2019).

5. Skrining Fitokimia

a. Flavonoid

Sampel diambil sebanyak kurang lebih 0,5 ml dicampur dengan $3 \mathrm{ml}$ etanol 70\%, lalu dikocok, dipanaskan dan dikocok lagi kemudian disaring. Filtrat yang diperoleh, kemudian ditambah $\mathrm{Mg} \mathrm{0,1} \mathrm{g}$ dan 2 tetes $\mathrm{HCl}$ pekat. Adanya flavonoid ditandai dengan warna merah, orange, dan hijau pada lapisan etanol (Harborne, 2006).

b. Saponin

Sampel diambil sebanyak 0,5 gramditambah dengan $10 \mathrm{ml}$ aquadestilata panas, didinginkan dan kemudian dikocok selama 10 menit. Terbentuknya busa yang stabil (bertahan lama) menunjukkan positif terdapat saponin (Harborne, 2006).

c. Tanin

Sampel diambil sebanyak 2 gram ditambah etanol sampai sampel terendam semuanya.Kemudian sebanyak $1 \mathrm{ml}$ larutan sampel dipindahkan kedalam tabung reaksi dan ditambahkan 2-3 tetes larutan $\mathrm{FeCl}_{3} 1 \%$. Hasil positif ditunjukkan dengan terbentuknya warna hitam kebiruan atau hijau (Harborne, 2006).

6. Uji Antibakteri

Uji aktivitas antibakteri fraksi daun biduri menggunakan metode difusi.Disiapkan media yang telah diinokulasi dengan bakteri. Disiapkan dan disterilkan kertas cakram diameter $6 \mathrm{~mm}$. Fraksi aquadestilata, etil asetat dan $n$-heksan daun biduri dengan berbagai konsentrasi $10 \%$, 
$20 \%$ dan $30 \%$ (b/v) ditambahkan pada masing-masing cakram sejumlah 20 mikropipet. Kertas cakram steril yang telah diresapi dengan ketiga fraksi tersebut ditempatkan pada permukaan media dengan pinset steril dan ditekan dengan lembut kebawah untuk memastikan kontak antara kertas cakram dengan permukaan media. Kontrol positif disiapkan dengan mencelupkan kertas cakram dalam kloramfenikol.Kontrol negatif disiapkan dengan mencelupkan kertas cakram dalam DMSO 10\%.Cawan petri diinkubasi pada suhu $37^{\circ} \mathrm{C}$ selama 24 jam.Kemudian diukur diameter zona hambat (Kusumowati et al., 2014).

7. Analisis Data

Data hasil penelitian aktivitas antibakteri fraksi daun biduri pada Staphylococcus aureus dianalisis menggunakan program SPSS 16 untuk mengetahui aktivitas antibakteri fraksi daun biduri terhadap bakteri Staphylococcus aureus.Pengolahan data dapat dilakukan dengan uji normalitas data, uji homogenitas, dan uji One Way Anova.

\section{HASIL DAN PEMBAHASAN}

Daun biduri sebagai bahan obat, sangat berkaitan dengan kandungan kimia yang terdapat dalam tanaman terutama zat bioaktif dalam tanaman.Daun biduri yang telah dilakukan determinasi dengan kunci 1b-2b-3b-4b-6b-7b-9b-10b-11b-12b-13b-14b-16a-239a-240b-241b-242b-1a-2b-3 dan sortasi basah kemudian dirajang untuk memperkecil ukuran sehingga mempercepat proses pengeringan. Hasil simplisia daun biduri diserbukkan dengan menggunakan blender untuk menghasilkan serbuk dengan ukuran mesh 80 . Serbuk simplisia daun biduri selanjutnya di uji kadar air dan dilakukan ekstraksi. Maserat difraksinasi dengan pelarut aquadestilata, etil asetat, dan $n$ heksana menggunakan metode partisi cair - cair. Hasil determinasi tanaman, uji kadar air simplisia, ekstraksi, dan fraksinasi disajikan pada Tabel I.

Tabel I. Hasil determinasi tanaman, uji kadar air simplisia, ekstraksi, dan fraksinasi.

\begin{tabular}{lc}
\hline \multicolumn{1}{c}{ Perlakuan } & Hasil \\
\hline Determinasi Tanaman & Tanaman biduri (Calotropis gigantean) \\
& \\
Uji Kadar Air Simplisia & $8,5 \%$ \\
Ekstraksi & $5,4 \%$ \\
Fraksinasi & \\
$\quad$ Aqudestilata & $30,6 \%$ \\
$\quad$ Etil asetat & $10,6 \%$ \\
$\quad n$-heksan & $14,6 \%$ \\
\hline
\end{tabular}

Skrining fitokimia dilakukan pada fraksi daun biduri. Skrining fitokimia dilakukan untuk mengetahui senyawa yang terkandung dalam daun biduri. Menurut Dewi et al., (2018), daun biduri memiliki kandungan senyawa aktif antara lain flavonoid, tanin, dan saponin.Hasil skrining fitokimia fraksi daun biduri dapat dilihat pada Tabel II.

Tabel II. Hasil skrining fitokimia fraksi daun biduri

\begin{tabular}{lccc}
\hline \multirow{2}{*}{ Nama fraksi } & \multicolumn{3}{c}{ Skrining Fitokimia } \\
\cline { 2 - 4 } & Flavonoid & Tanin & Saponin \\
\hline Fraksi Aquadestilata & + & + & + \\
Fraksi etil asetat & + & + & - \\
Fraksin-heksan & + & + & - \\
\hline Ket: $(+)$ men
\end{tabular}

Ket : (+) mengandung senyawa (-) tidak mengandung senyawa

Hasil skrining fitokimia fraksi daun biduri menunjukkan bahwa pada fraksi Aquadestilata mengandung senyawa flavonoid, saponin dan tanin, pada fraksi etil asetat mengandung senyawa flavonoid dan tanin, sedangkan pada fraksi $n$-heksan mengandung senyawa flavonoid dan tanin. 
Uji aktivitas antibakteri fraksi daun biduri terhadap bakteri Staphylococcus aureus ATCC 25923 menggunakan metode difusi cakram dengan suhu inkubasi $37^{\circ} \mathrm{C}$ selama 24 jam. Daya antibakteri fraksi daun biduri dapat dilihat dari ada atau tidaknya zona bening disekitar kertas cakram. Hasil zona hambat uji aktivitas antibakteri fraksi daun biduri dapat dilihat pada Tabel III.

Tabel III. Hasil zona hambat uji aktivitas antibakteri fraksi daun biduri

\begin{tabular}{|c|c|c|c|c|c|c|}
\hline \multirow[t]{2}{*}{ Sampel } & \multirow[t]{2}{*}{ Konsentrasi } & \multicolumn{3}{|c|}{ Replikasi (mm) } & \multirow{2}{*}{$\begin{array}{l}\text { Rata- } \\
\text { rata }\end{array}$} & \multirow[t]{2}{*}{ SD } \\
\hline & & 1 & 2 & 3 & & \\
\hline \multirow{5}{*}{$\begin{array}{l}\text { Fraksi } \\
\text { Aquadestiata }\end{array}$} & Kloramfenikol & 24,0 & 27,0 & 24,0 & 25,0 & 1,7 \\
\hline & DMSO $10 \%$ & 0,0 & 0,0 & 0,0 & 0,0 & 0,0 \\
\hline & $10 \%$ & 7,0 & 6,0 & 6,0 & 6,3 & 0,5 \\
\hline & $20 \%$ & 10,0 & 10,0 & 9,0 & 9,6 & 0,5 \\
\hline & $30 \%$ & 16,0 & 15,0 & 15,0 & 15,3 & 0,5 \\
\hline \multirow{5}{*}{$\begin{array}{c}\text { Fraksi Etil } \\
\text { Asetat }\end{array}$} & Kloramfenikol & 25,0 & 25,0 & 26,0 & 25,3 & 0,5 \\
\hline & DMSO $10 \%$ & 0,0 & 0,0 & 0,0 & 0,0 & 0,0 \\
\hline & $10 \%$ & 5,0 & 4,0 & 4,0 & 4,3 & 0,5 \\
\hline & $20 \%$ & 8,0 & 8,0 & 7,0 & 7,6 & 0,5 \\
\hline & $30 \%$ & 9,0 & 8,0 & 7,0 & 8,0 & 1,0 \\
\hline \multirow{5}{*}{$\begin{array}{c}\text { Fraksi } n \text { - } \\
\text { heksan }\end{array}$} & Kloramfenikol & 25,0 & 27,0 & 26,0 & 26,0 & 1,0 \\
\hline & DMSO $10 \%$ & 0,0 & 0,0 & 0,0 & 0,0 & 0,0 \\
\hline & $10 \%$ & 0,0 & 0,0 & 0,0 & 0,0 & 0,0 \\
\hline & $20 \%$ & 0,0 & 0,0 & 0,0 & 0,0 & 0,0 \\
\hline & $30 \%$ & 0,0 & 0,0 & 0,0 & 0,0 & 0,0 \\
\hline
\end{tabular}

Hasil penelitian menunjukkan bahwa fraksi Aquadestilata dan fraksi etil asetat memiliki aktivitas antibakteri terhadap Staphylococcus aureus dengan ditandai adanya zona bening di sekitar kertas cakram pada konsentrasi 10\%, 20\%, dan 30\%, sedangkan pada fraksi n-heksan tidak memiliki zona hambat. Rata-rata zona hambat yang dihasilkan kloramfenikol pada uji aktivitas antibakteri fraksi Aquadestilata adalah $25,00 \mathrm{~mm}$, pada uji aktivitas antibakteri fraksi etil asetat memiliki rata-rata $25,33 \mathrm{~mm}$, dan pada uji aktivitas antibakteri fraksi n-heksan memiliki rata-rata 26,00 mm.Pada fraksi Aqudestilata pada konsentrasi $10 \%$ sebesar 6,33 mm, pada konsentrasi $20 \%$ sebesar 9,67 mm, pada konsentrasi $30 \%$ sebesar 15,33 mm. Hasil tersebut menunjukkan bahwa pada konsentrasi $10 \%$ dan $20 \%$ termasuk kategori sedang dan pada konsentrasi $30 \%$ termasuk kategori kuat. Zona hambat fraksi etil asetat pada konsentrasi $10 \%$ sebesar $4,33 \mathrm{~mm}$, pada konsentrasi $20 \%$ sebesar 7,67 mm, dan pada konsentrasi $30 \%$ sebesar $8 \mathrm{~mm}$. Hasil tersebut menunjukkan pada konsentrasi $10 \%$ termasuk kategori lemah dan pada konsentrasi $20 \%$ dan $30 \%$ termasuk kategori sedang. Zona hambat fraksi n-heksan pada konsentrasi 10\%, 20\%, dan 30\% menunjukkan hasil $0 \mathrm{~mm}$ sehingga fraksi $n$-heksan tidak dapat menghambat aktivitas antibakteri Staphylococcus aureus.

\section{KESIMPULAN}

Berdasarkan hasil dan pembahasan dalam penelitian ini dapat disimpulkan bahwa fraksi Aquadestilata dan fraksi etil asetat daun biduri memiliki aktivitas antibakteri terhadap bakteri Staphylococcus aureus. Fraksi Aquadestilata memiliki zona hambat paling luas sebagai antibakteri Staphylococcus aureus.Konsentrasi optimum fraksi Aquadestilata daun biduri sebagai antibakteri terhadap bakteri Staphylococcus aureus adalah 30\%. 


\section{DAFTAR PUSTAKA}

Amelinda, Ega., Widarta, R. W., 2018, Pengaruh Waktu Maserasi Terhadap Aktivitas Antioksidan Ekstrak Rimpang Temulawak (Curcuma xanthorriza Roxb). Jurnal Ilmu \& Teknologi Pangan. Vol. 7, No. 4, p : 165-174

Dewantari, Rinika., Lintang, Monika., Nurmiyati., 2018. Jenis Tumbuhan Yang Digunakan Sebagai Obat Tradisional Di Daerah Ekskaresidenan Surakarta.Journal. Vol. 11, No. 2, p : $118-123$

Dewi, Desak, G. D., Mastra, Nyoman., Jirna, Nyoman., 2018, Perbedaan Zona Hambat Pertumbuhan Staphylococcus aureus Pada Berbagai Konsentrasi Ekstrak Etanol Daun Biduri Secara In Vitro. Vol. 6, No. 1, p : 40

Hasanah, Mu'akibatul, 2019. Aktivitas Antineuroinflamasi Fraksi N-Butanol Daun Semanggi (Marsilea crenata C. Press) Secara In Vitro Pada Sel Mikroglia HMC3. Skripsi. Malang : Universitas Maulana Malik Ibrahim

Katrin, Dina., Idiwati, Nora., Sitorus, Berlian. 2015. Uji Aktivitas Antibakteri Dari Ekstrak Daun Malek (Litsea graciae vidal) terhadap Bakteri Staphylococcus aureus dan Escherichia coli. JKK. Vol. 4, No. 1, p : 7-12

Kusumowati, Ika Trisharyanti Dian., et al., 2014. Daya Antibakteri Ekstrak Etanol Daun Senggani (Melastoma affine D. Don). Biomedika. Vol. 6, No. 2.

Mutiasari, IR. 2012. Identifikasi Golongan Senyawa Kimia Fraksi Aktif. Journal Ilmiah. Jakarta : FMIPA-UI

Nadziroh, Masluhatin. 2014. Uji Sitotoksisitas Ekstrak Daun Widuri (Calotropis gigantea. L) Terhadap Larva Udang Artemia salina Leach Dan Identifikasi Golongan Senyawa Aktifnya. Skripsi. Malang : Universitas Maulana Malik Ibrahim

Susanty., Bachdim, Fairus. 2016. Perbandingan Metode Ekstraksi Maserasi dan Refluks terhadap Kadar Fenolik dari Ekstrak Tongkol Jagung (Zea mays L.).Konversi. Vol. 5, No. 2, p : 8793 